https://doi.org/10.18485/iipe_response2covid19.2021.ch3

\title{
THE COVID-19 POLICIES OF POLITICAL GROUPS IN THE EUROPEAN PARLIAMENT
}

\author{
Ekrem Yaşar Akçay ${ }^{1}$ \\ Halil Emre Deniş̧
}

\begin{abstract}
This study will examine the position of political groups in the European Parliament (EP), the first institution of the European Union (EU), and the COVID19 policies of these groups in a comparative method. With different ideologies and different policies, these groups had seats in the EP after the 2019 elections. The study's main issue is to determine what kinds of policies these groups have pursued in the face of a global crisis, as well as how close and overlapping these policies are. The study consists of two parts. In the first part, the ideologies, values and policies of the political groups, which took part in the Parliament according to the 2019 EP election results, will be examined, and in the second part, the policies of these political groups against the COVID-19 pandemic will be examined and evaluated with a comparative perspective.
\end{abstract}

Keywords: European Parliament, European Union, Political Group, COVID-19, Crisis, Pandemic Process.

\section{INTRODUCTION}

As one of the most important institutional bodies of the EU, the EP usually adopts European legislation on the proposal of the European Commission, and the member states can take binding decisions together with the European Council. It represents the largest transnational democratic voting system in the world (David and David, 2003). Since 1979, "the EP has been composed of representatives of the Union's citizens. Members of the EP are elected by direct universal suffrage in a free and secret ballot for a period of five years" (Official Journal of the European Union, 2012).

\footnotetext{
${ }^{1}$ Professor, Hahary University, Turkey, ekremyasarakcay@hakkari.edu.tr.

${ }^{2}$ Professor, Hahary University, Turkey, halilemredenis@hakkari.edu.tr.
} 
Although the EP has legislative power like the Council, it does not formally have the right to take the initiative as most national parliaments of the member states do (Marguand, 1979). The EP, the first institution of the EU, shall, jointly with the EU Council, exercise legislative and budgetary functions (Official Journal of the European Union, 2016). After Brexit, in the EP, which consists of 705 Parliamentarians, there are seven political groups, and the members are organized according to political affiliation/affinity with political groups (Archick and Mix, 2011). The members can enrol only in one group. Yet, some members are not members of a certain group and continue their work independently. No group has an absolute majority in the EP. For this reason, coalition building has been an important element of the legislative process (Bressanelli, 2012).

Political groups contribute to the EP's operational capability and efficiency. Each political group takes care of its own internal organisation by appointing a chair, a bureau, and a secretariat. In addition, the EP and the Council of the EU determine, through regulations, the regulations governing political parties at the European level. Although most national parties represented within a particular political group are also members of the corresponding political party at the EU level, some political groups bring together more than one European political party (Official Journal of the European Union, 2016).

Alleged to have spread all over the world, starting in Wuhan, China, at the end of 2019, COVID-19 has affected the whole world and has become an important problem. The EU, which failed to show the expected effect in the early stages of the coronavirus process, experienced serious reactions and criticism from the member states. Moreover, a state like Italy, which is the founder of the EU, said that the EU was not by its side during the COVID-19 Crisis, and many politicians removed the EU flag from their chambers. Later, although the EU tried to be effective by providing financial support to its member countries within the scope of combating COVID-19, it continued to receive criticism for being late in the intervention (Adler, 2020).

This study will examine the COVID-19 policies of political groups in the EP and examine these policies in a comparative method. In general, the main pain point of the study is to find out what kind of policies the political groups with different ideologies and ideas act with regarding the COVID-19 crisis. The study consists of two parts. In the first part, the historical processes, ideologies and policies of the political groups in EP will be examined. In the second part, the perspectives of political groups on the COVID-19 policies will be evaluated.

\section{POLITICAL GROUPS IN THE EUROPEAN PARLIAMENT}


The parliamentary numbers of the member countries in the EP are determined according to the population density. The members of the European Parliament are not organised by nationality but by political affiliation. There are currently seven political groups in the European Parliament. Members who do not belong to any political group are known as non-attached Members. The places assigned to the members in the Chamber are decided by political affiliation, from left to right, by agreement with the group chairs (Kaczorowska, 2009).

Table 1. Political Groups in the European Parliament (2019)

\begin{tabular}{|l|c|}
\hline \multicolumn{1}{|c|}{ Party } & Seat \\
\hline European People's Party (Christian Democrats) (EPP) & 187 \\
\hline Progressive Alliance of Socialists and Democrats(S\&D) & 145 \\
\hline Renew Europe (Renew) & 98 \\
\hline Identity and Democracy (ID) & 75 \\
\hline The Greens- European Free Alliance (The Greens/EFA) & 73 \\
\hline European Conservatives and Reformists Party(ECR) & 62 \\
\hline European United Left/ Nordic Green Left(GUE/NGL) & 39 \\
\hline Non-attached Members (NI) & 26 \\
\hline Toplam & 705 \\
\hline
\end{tabular}

\section{The European People's Party (Christian Democrats) (EPP)}

Although the EPP, the largest international political party in Europe, was officially founded in 1976, it traces its roots back to the history of the European continent (EPP, 2020a). The EPP is a centre-right party with a Christian Democratic, conservative and liberal-conservative ideology. Combining Christianity and conservatism, the EPP advocates the principles of freedom, justice and solidarity that support family values. Protecting its Biblical and Christian cultural heritage, the EPP also supported the construction of the social Christian individual. The EPP, which defends a federal Europe, will both preserve the diversity within the Union and open the way to find common solutions to problems (Kiris, 2013).

It emphasized policies such as creating new jobs economically, preventing protectionist policies, supporting fiscal and monetary policies, ensuring 
transparency and surveillance in financial markets, making Europe a market leader in green technology, combating climate change, the share of renewable energy by at least $20 \%$ by 2020 to create a new strategy that would attract skilled workers from the rest of the world to make Europe's economy more competitive, more dynamic and more knowledge-oriented, family-friendly flexibility for working parents, better child care and accommodation, family-friendly financial policies, and the promotion of parental leave (Euractiv, 2009). Stating in the 2019 EP election statement that the world is a less secure place and that new threats such as instability and uncontrolled power in authoritarian neighbouring regions such as Russia and China have emerged, the EPP said that they would overcome everything together and create a livable new Europe, where they could protect Europe from external threats, and that they would lead Europe further than their Founding Fathers (EPP, 2019a).

\section{The Progressive Alliance of Socialists and Democrats (S\&D)}

The $S \& D$, the second-largest party in the EP, is the European Socialist Party and a centre-left party close to the left, and its origins can be traced to the working group Socialist Integration, formed in 1951 to discuss the Schuman Declaration (Hix and Urs, 2002). The S\&D concentrates on a number of issues, such as ensuring equality of men and women, regulation and improvement of minimum wages and military working hours, protection of consumers, protection of the environment, fight against organized crime, ensuring peace, and ensuring more active participation of EU citizens in the decision-making process of the Union. Within the framework of the EU 2020 Strategy, it focuses on protecting green, combating climate change, ensuring justice in taxation, creating a sustainable economic structure, establishing dialogue and cooperation with China, the US, Russia and Latin American countries. In the 2019 election statement, the S\&D focused on equality, justice, democracy, and human rights, including gender equality, youth and their future, the environment and sustainability, and shelter and immigration policies. Stating that the EU should serve people more, the S\&D stated that they should create a fairer Europe and change the EU (Kiris, 2013).

\section{Renew Europe (Renew)}

Renew Europe, a liberal and pro-European group, is a continuation of the Alliance of Liberals and Democrats for Europe (ALDE) (European Parliament, 2019a). Renew is the third-largest group in the EP. Saying that the EU will find a 
solution to the problems in the EU and meet the needs of the people, Renew states that it will fight for a free and fair Europe (Renew Europe, 2020a).

Stating that the European Digital Single Market and common digital rules and standards, which will eliminate borders in the digitalizing world, are necessary, Renew emphasizes that a structure that everyone can buy whatever they want from where they want, access all the information they want when and where they want and go wherever they want will be better for Europe. In addition to this, supporting the creation of a federal Europe, Renew believes that strong security and a stable Europe can only be achieved with a federal structure. Referring to the existence of important problems such as cyber security in the world, Renew said that no one could fight the cyber threat alone, so Europe should be in cooperation more than ever (ALDE, 2018). Stating that unemployment is also one of the most important issues in Europe, Renew emphasized that providing new job opportunities and increasing employment were among the priority targets. Saying that Europe is in a crisis due to economic, political and security problems, Renew stated that the EU was ineffective and late in solving these crises and that a more effective and more integrated Europe should be provided (Renew Europe, 2019).

In order to solve all the existing problems, The Renew Group said that they would fulfil the main tasks of the institutions within the structure of the EU, such as the EP. The legal legislation regarding their duties would be simplified, the duties of all institutions would be stated clearly, the democratic deficit problem in Europe would be solved, European values would be preserved and an EU would be formed where European citizens could establish closer ties with the EU. Renew stated that the problems within the EU would be easily solved (Renew Europe, 2020b).

\section{The Identity and Democracy Group (ID)}

The ID Group, which is the continuation of the European Group of Nations and Freedoms, is the fourth most powerful group of the EP. The ID, the far-right party, has an ideology that is nationalist, European sceptical, anti-immigrant, and pro-identity and sovereignty (Adams, 2019). Established with the aim of creating new jobs, growth and development, enhancing the security of Europe, combating illegal immigration and combating the EU's cumbersome bureaucracy, the group defines itself as a defender of sovereignty rather than being a European sceptic. In this sense, the ID believes that the sovereignty of states and peoples is based on cooperation between nations and therefore rejects any policy designed to establish a supra-state or supranational model. The objection to any transfer of national sovereignty to supranational bodies and European institutions has been 
one of the fundamental principles uniting the members of the ID (Identity and Democracy Group, 2019).

Saying that the democratic deficit in the EU must be resolved, the ID believes that this problem will be overcome by the more active participation of national parliaments in the decision-making process. The ID, which opposes the full membership of non-European states such as Turkey in the EU, also aims to prevent the spread of Islam in Europe (Huet, 2019). As the members of the group handle their political activities within the framework of democratic principles, they reject authoritarian activities or projects linked to them. The group bases its political movements on the defence of individual freedoms and emphasizes the special importance of protecting freedom of speech, including digital freedoms that are increasingly endangered today (Identity and Democracy Group, 2019).

The ID recognizes each other's right to defend each other's unique economic, social, cultural and regional models. In this sense, the ID tries to preserve the diversity of its members' political projects. The ID bases its political alliances on the preservation of the identities of European peoples and nations in accordance with the specific characteristics of each people. The right to control and regulate migration has therefore been a fundamental principle shared by ID members (Identity and Democracy Group, 2019).

\section{The Greens/European Free Alliance (Greens/EFA)}

The Greens and the European Freedom Alliance formed a group in the EP in 1999. The alliance with the majority of Greens aims to create a society that respects human rights, to increase employment, to ensure active participation of individuals in the EU decision-making process, to develop democracy, to strengthen transparency in the EU and establish a free Europe (Yatagan, Akman \& Kiris, 2017). There is a co-chair system in the group, and gender equality is guaranteed.

After the union of the Greens/EFA, their aims became to create a society that respects nature and human rights, to increase freedoms, to create an employment environment that highlights the potential of people in Europe, to ensure the active participation of EU citizens at the local level, to expand democracy, protect social rights, protect the climate and the environment to make legal arrangements, to ensure the transition to a green economy, to ensure the efficient use of energy, to protect cultural values, to combat regionalism, discrimination and to create a transparent market (The Greens/EFA, 2020a).

In addition, with direct participation in the procedures such as the right to self-determination, housing, health, education, culture and high quality of life, 
decentralization and deepening democracy, solidarity, and human rights for people from non-EU states, the Greens/EFA group strives to secure their rights, solve problems peacefully, protect women's rights, ensure cultural diversity, and build an EU of free peoples (The Greens/EFA, 2020b).

\section{The European Conservatives and Reformists Group (ECR)}

The ECR is a European sceptic and anti-federalist political group of the EP founded in 2009 (European Parliament, 2019b). Ideologically, the group is a European sceptic, an anti-federalist, and right-wing. Its main focus is to advocate free-market policies and stricter controls on immigration, as well as opposing uncontrolled European integration and the transformation of the EU into a Federal European State. The ECR includes a mix of social conservative, right-wing populist, liberal-conservative, Christian democratic, nationalist and national conservative parties, all of which share anti-federalist and European scepticism. Some parties within the ECR advocate soft European scepticism against the complete rejection of the EU, calling for democratic reform in the EU and limiting some of its powers and bureaucracy while protecting it from restriction. Other parties and individual MPs within the group support the complete withdrawal from the block, referendums on EU membership, and opposition to the Eurozone (ECR, 2020).

The priorities of the group, established in 2009, are contained in the text known as the Prague Declaration. According to this declaration, free enterprise, free and fair trade and competition, minimum regulation, lower taxation, individual freedom, more personal responsibility and more democratic accountability, sustainable, clean energy as the ultimate catalyst for individual freedom, personal and national well-being, supply and energy security, the importance of the family as the foundation of society, nation-state sovereignty, opposition to EU federalism and power substitution, supporting the development of democracy, ending the abuse of effectively controlled immigration and asylum procedures, ensuring transparency and honesty, stimulating relations with NATO, ending the EU's cumbersome bureaucracy have been the priorities of the ECR (ECR, 2013a).

\section{The European United Left/Nordic Green Left (GUE/NGL)}

Established in 1995, the GUE/NGL has a democratic left and socialist ideology. (GUE/NGL, 2020a). Increased employment, better and quality education opportunities in the integration process, social security, social solidarity, proper utilization of the world and resources, cultural change and continuity, sustainable 
economic development, peace, democracy, active participation of EU citizens in the decision-making process are the main ideologies of the party. At the same time, the party, which wants to make the EU a project of the people rather than the project of the elites, has an ideology against fascism and racism that wants to improve gender equality and human rights (GUE/NGL, 2020b).

The group that advocates Confederalism in the EU says that Confederalism means respecting and protecting members' identity and diversity of opinion. According to the GUE/NGL, what holds them together is the vision of a socially egalitarian, peaceful and sustainable European integration process based on international solidarity. Stating that Europe has made a great contribution to improving the living conditions of many people, the party claimed that the EU would be more successful if it had a confederal structure (GUE/NGL, 2020b).

According to the 1994 founder declaration, the group opposes the current EU political structure but is determined to continue integration from a different dimension. In addition, this declaration sets out three objectives for the building of another EU. The first of these is the complete change of institutions in order to make them fully democratic, the second is the break with neoliberal policies, and the third is the policy of egalitarian cooperation that will enable development together. The group wanted to disband NATO and strengthen the OSCE (GUE/NGL, 1994).

\section{THE COVID-19 POLICIES OF POLITICAL GROUPS IN THE EUROPEAN PARLIAMENT}

The COVID-19 epidemic, which is claimed to have started in China at the end of 2019 and spread rapidly all over the world, has caused negative effects, such as economic, social, political and health in many areas all over the world. The effects were just like dominoes, and this process seriously affected the EU. In the EU, which was caught unprepared for this process since public health policies are under the jurisdiction of the member states, the member states have taken measures against the pandemic to a greater extent than the EU. Along with this, the supranational structure of the EU prevented early intervention against the pandemic due to the fact that the decisions were not taken in a timely and joint manner. For example, the President of the European Commission announced the package of measures against the pandemic 47 days after the first cases appeared in Europe, and the member states tried to take measures until then (Nas, 2020). This situation has led to the questioning of both the EU and its values that are the reason for its existence. In such an environment, the COVID-19 policies of the political groups in the European Parliament, which is one of the main institutions 
of the EU and makes binding decisions on the member states, have also been important. They certainly influenced their thoughts towards the EU.

The EPP emphasized that it faced a global public health threat and that the EU needed effective actions to solve this problem. This is why the EU health policy should focus on areas where true European added value can be produced. Stating that the EU should demonstrate its ability to draw accurate conclusions and take action from the impact of the COVID-19 pandemic more than ever, the EPP stated that joint action must be taken for the benefit of the total population and frontline healthcare workers, and emphasized that in such difficult times, there was a need for solidarity between member states and quickly developed and well-coordinated approaches at the EU level. (EPP, 2020b).

According to the EPP, reducing the further spread of the virus is a prerequisite for a lasting economic recovery. Public health and a strong economy are interdependent, as improving health system resilience is an investment in future economic well-being. In addition to this, the nature of a global health crisis requires decisive and concrete action at the EU level in the health sector, which allows for a better EU in crisis prevention and crisis management. The member states and EU institutions should work cooperatively together for an EU that can empower the member states to prevent and manage future health crises in a more coordinated way (Brotman, 2020).

Emphasizing the need for the EU to be active and dominant in health issues in difficult times, the EPP has helped prevent future shortages in the EU against critical medical products, improve access to and availability of health data, and strengthen the EU's role in global health. The EU, an ambitious proposal from the European Commission for the EPP, is a crucial step towards Europe's recovery and its rapid and convincing adoption should be a top priority for the EU. To better prepare the EU for future health emergencies, to enable it to respond quickly and decisively, and to reduce dependence on third countries in the field of health, should be the core lesson learned from the current epidemic in order for the EU to play a crucial role in protecting health. Because if some lessons are learned from this crisis, the welfare of the citizens will be ensured, and it will be possible to get out of the crisis stronger (EPP, 2020b).

In the EU, the COVID-19 process caused significant casualties and economic recession. There are important debates on how to deal with the economic crisis and its social impact, as well as public health. Ultimately, as in the past, this crisis reveals the increasing limits of the interdependence of the member states and the EU, as well as the need for more effective multilateral cooperation. For this reason, it has shown once again that the EU needs to improve its relations within itself and with other countries and its neighbours. Emphasizing the importance 
of relations with China in this sense, the EPP said that the pandemic clarified the increasing importance of the EU's relations with China. It was emphasized that the cooperation between China and the EU should be strengthened both in combating the difficulties of the pandemic and in order to get stronger by taking advantage of China's new situation (EPP, 2020b).

Stating that COVID-19 affected the whole world and that the impact of COVID19 on society increased day by day, the S\&D said that the EU remained ineffective. The S\&D, which created an action plan to combat COVID-19 on March 25, 2020, made a number of recommendations, such as investing in research and efficient data sharing across the EU for effective treatment and a potential vaccine against COVID-19, which should be accessible to all, creating Corona bonds as soon as possible, activating the European Stability Mechanism (ESM) with a certain credit limit, initiating a temporary European minimum income program to protect everyone, protecting the unimpeded transportation throughout the Single Market, investing in quality access to the internet to spread digitalization to all areas and taking preventive measures for refugees and asylum seekers, to the EU (S\&D, 2020).

Emphasizing the importance of investing in public health systems in Europe and building new and more active policies in the fight against COVID-19, the S\&D also noted the need for the member states to strengthen the recruitment of medical personnel and provide adequate resources for salaries and medical equipment to national health systems. The S\&D emphasized the need to provide financial power to sustain the EU's long-term sustainable development and the European Green Deal. Saying that it is necessary to be constructive in the process of COVID-19, the S\&D leader Iratxe García also said that the whole world should be vaccinated in an unprecedented challenging environment, that vaccine nationalism would not work, that vaccination would improve the EU's health system to be open and transparent, and increase production. If the EU is problemoriented and works in cooperation with international organizations, this difficult process will come to an end (European Parliament, 2021a). However, the Environment Committee coordinator, Jytte Guteland, said that vaccination was the only way to get rid of the crisis (European Parliament, 2021a). Stating that Europe and the world were in a deadly race against time, and the crisis would be prevented by increasing production, the development committee Udo Bullmann emphasized that the EU should play a more active role. Economy and monetary affairs spokesperson Jonás Fernández said that since the COVID-19 crisis had affected households and companies, measures must be taken for SMEs to improve access to investments, protect investors and guarantee full price transparency (European Parliament, 2021b). 
Renew, another group that says the EU has been ineffective in the face of the COVID-19 pandemic, called for more ambitious EU actions to defeat COVID-19. The Renew asked the EU to be more ambitious and reduce pressure on health and the economy in order to save lives. The group called on the EU to move faster. The President of Renew, Dacian Cioloș, said that considering the scale of this crisis, the measures of the first emergency package were simply insufficient and that they would support the first support package of the EU. He stated that more ambitious measures were needed in the fight against COVID 19, and these must be implemented very quickly to save lives and protect jobs (Renew Europe, 2021).

However, the Renew warned that it could affect the EU not only economically but also culturally. Stating that culture has an important role in Europe, Renew stated that the cultural world was inactive due to the COVID-19 epidemic and that culture should not be abandoned since it was a vital part of European identity and an important sector of the economy. Therefore, Renew stated that a strong commitment was needed to revitalize European culture. For Renew, an uncultured Europe is meaningless in the economy and other fields. It emphasized that a permanent connection with European citizens should be established in this regard (Renew Europe, 2021).

Arguing that COVID-19 is a "game changer", Renew stated that it would increase the socio-economic and political risks by changing the context of external relations and global security issues and stated that some of the values that the EU had been trying to promote for decades might be damaged if the necessary measures were not taken. Renew emphasized the necessity of global cooperation in this process and said that the EU remained ineffective and weak in this environment by drawing attention to the lack of global leadership and cooperation in the early stages of COVID-19. Stating that better digital and communication strategies were needed to be more resilient to new threats and technologies, Renew underlined that ending the unanimity rule in foreign relations would help make the EU a more active player, as the recent sanctions showed. In this sense, a united and determined European presence on the world stage has become an absolute necessity for Europeans to defend their interests internationally. The ID highlighted the serious impact of the crisis on the European population and the need for a new assessment for Europe by saying that citizens who had to stay in their homes and did not have freedom of movement did not trust their managers. The political leaders of the EU and its member states were unable to fulfil their duties due to their unpreparedness and unlimited ideological stubbornness. Moreover, in this process, it was seen that the EU member states rather than the EU were more active in resolving the crisis (Identity and Democracy Group, 2021). 
The Greens/EFA have also seriously criticized the EU during the COVID-19 process. On the other hand, they found the fund created by the EU important. The 672.5 billion euro fund was seen as the cornerstone of the EU's COVID-19 economic recovery plan. This fund is designed to provide significant support to EU countries in dealing with the economic impact of the epidemic, in line with the EU's priorities on climate and digital transition. While the EFA President, Jordi Solé, praised the fund as a historic success, he emphasized that for its implementation to be a real success, it must be thoroughly planned (The Greens/EFA, 2021a).

On the vaccination issue, the Greens/EFA said that there was a need for a wellfunctioning systematic EU for issues such as global and equal access to vaccines, state support for vaccine production, and the temporary abolition of patent rights. While Ska Keller, president of the Greens/EFA, said that the Greens/EFA stood behind a common European approach to vaccine supply, and investment in vaccine production was necessary to save lives, he also stated that the European Commission should suspend intellectual property rights for a process of time for rapid and equal distribution. Besides, Keller emphasized that nobody would be protected from the pandemic until everyone was protected, and that this virus should not be allowed to deepen global injustices, so it was necessary to take responsibility and be solidary. According to Keller, there is a need for equal access to vaccines globally. Otherwise, it will be difficult to control the pandemic (The Greens/EFA, 2021b).

Philippe Lamberts from the Greens/EFA stated that every procedure regarding the vaccine should be shared with the public, that investment was needed for vaccine production capacities, and that the spread rate of the virus could be prevented with a systematic study. The Greens/EFA, which warned the EU about the initiation of the green and digital process in the fight against COVID-19, emphasized that this process would also contribute to economic development (The Greens/EFA, 2021a).

Also, the ECR believes that the EU should make more efforts to fight the virus. For the ECR, the EU should be an organization that connects the member states, allowing them to live, work and travel without unnecessary barriers and bureaucracy. Therefore, the EU should strive to reduce barriers within the single market, facilitate buying and selling products within the EU, ensure the protection of consumer rights in all member states, and improve the basic infrastructure and accessibility of the transport sectors (ESR, 2020).

A key priority for the ECR Group is to end the stifling regulation imposed by the $\mathrm{EU}$ on businesses. According to the ECR, there is an unnecessary and cumbersome bureaucracy within the EU. To reduce cumbersome bureaucracy and unnecessary laws will ensure the efficient functioning of EU policies (ESR, 2021). 
The ECR, which makes recommendations to minimize the economic losses of the EU countries and citizens while tackling COVID-19 and favours stretching the existing bureaucratic and legal practices of the EU to stimulate the economy, spoke of the EU's concerns about the COVID-19 Vaccination Strategy. The ECR stated that the EU was slow about vaccines and that the future of the EU depended on the health of people and the economies of the EU countries. Stating that the EU was not innovative enough in vaccine production, the ECR Group emphasized that the EU should take the necessary measures as soon as possible and that this would help overcome the crisis (SDRC, 2020).

The GUE/NGL also criticized the EU for its COVID policy. According to them, while people face the destruction of COVID-19, the EU makes stereotypes. While robust measures are needed to overcome this crisis, according to GUE/NGL, the EU does not do this (GUE/NGL, 2020c). Manon Aubry, one of the GUE/NGL CoChairs, said that the EU had failed to respond adequately to the ongoing crisis, but needed a much better plan from European institutions. Martin Schirdewan, another GUE/NGL co-chairman, said that as EP members, instead of choosing a fair solution of the European Coronabonds supported by the ECB, they should condemn the outcome of the Eurogroup meeting, which agreed to mobilize the ESM's austerity trap. Furthermore, Schirdewan stated that the most stringent measures should be taken to protect the lives, health, and incomes of workers, unemployed people, women, people living in poverty, and especially those who are particularly vulnerable during this epidemic, such as refugees and homeless people. He stated that they had proposed a comprehensive set of policies in many areas, from health to education (GUE/NGL, 2020c).

Stating that fundamental rights and freedoms should not be ignored in the solution of the crisis, Schirdewan said that an unprecedented crisis was experienced and that a policy based on protecting life should be acted upon. According to the GUE/NGL, the EU must invest heavily in response to the epidemic and be unconditionally backed by the full force of the ECB. In addition, urgent and massive public expenditures should be made to support health systems that were unprepared for the crisis and destroyed by the austerity policies imposed by the EU in many countries. Also, the group, who said that the EU should be ready to take radical measures in vital sectors in order to contain this crisis, emphasized the protection of jobs, income and social security (European Parliament, 2020).

\section{CONCLUSION}

Political groups in the EP criticized the EU on the basis that it was caught unprepared and ineffective in the COVID-19 process, and emphasized that the EU 
should develop policies that would be more active in such crises, and stated that it could only survive potential crises in this way. The EPP, one of the political groups, sees it as a precondition for economic recovery and stated that EU member states should work in solidarity and coordination in order to get out of this process quickly. The S\&D, on the other hand, makes suggestions such as providing financial support to do research on vaccines, stocking medical supplies, eliminating the disruptions in the Single Market, allocating economic resources to the public and small businesses, supporting workers and SMEs, facilitating access to investments. They also stated that the EU should engage in this process in an open, transparent, problem-solving, production-increasing, global cooperation.

Renew, on the other hand, emphasized the importance of not only the economy but also culture in the process of COVID-19 by saying that the EU should protect human life and employment in this crisis. Renew also stated that culture had remained inactive due to COVID-19, and they claimed that if this element, which was one of the most important parts of the EU, were not revived, other areas, such as human rights, would also fail. Stating that the importance of digitalization has increased with COVID-19, Renew emphasized that the EU should have an effective and strong digital communication strategy. On the other hand, the ID stated that the EU was caught unprepared for this process and could not fully fulfil its task, and the ID said that this process would be resolved through sovereign states rather than the EU.

Stating that climate and digitalization should also be given importance in the fight against COVID-19, the Greens/EFA believed that a systematic EU could produce more solution-oriented policies. Emphasizing that no one can be protected without protecting everyone, the group stated that global and equal access to vaccines should be provided, and in this sense, it would be beneficial for the EU to suspend its intellectual and property rights for a while.

The ECR stated that if the barriers in the Single Market were reduced, and the cumbersome bureaucratic structure within the EU was regulated, the EU could work more efficiently and economic development could be achieved more easily. Lastly, the group stated that the EU should be more effective in its measures to solve the GUE/NGL problems and stated that investments were important in this process, as well as fundamental rights and freedoms, and they should never be ignored.

Generally speaking, the political groups that stated that the EU was insufficient in this process focused on the need for an EU that acted on the basis of global cooperation and was active in every field. But due to the problems arising from the institutional structure of the $\mathrm{EU}$, it is very difficult to form a common position among the member states. As the EPP points out, which cannot make a joint 
decision in times of crisis and therefore intervenes late in solving the crisis in the EU, it is not possible to create solidarity and coordination in the COVID-19 crisis. On the other hand, it will not be easy for the EU, which was severely affected by the global economic crisis of 2008, to provide the expected financial support for this crisis. Moreover, it is difficult to put into action the humanitarian rhetoric and equality of the EU, which intervened late in the crisis and could not make a joint decision on vaccines. The use of bureaucracy in the EU decision-making structure slows the process down. On the other hand, as the Greens/EFA group says, proposals to take measures to protect the climate and greens do not seem applicable or sustainable as the EU is struggling with a crisis such as COVID-19. Therefore, in such a crisis period, the rhetoric and suggestions of the political groups in the EP do not reflect much truth since they are mostly designed according to their own ideology. In addition, as all political groups stated that in the age of digitalization, policies for digitalization in this process seemed realistic. It also seemed more likely that if the EU prioritized digitalization efforts, it would achieve a successful result.

In this context, if the EU wants to consolidate its future position, it must move forward with a structure that can make quick and common decisions, intervene urgently in crises, put bureaucracy second, and prioritize the interests, demands and wishes of its citizens. Otherwise, as the Renew Group points out, the EU's response to crises will decrease day by day, and as it is a structure where culture and ideology are prioritized, this will also increase vaccine nationalism during the COVID-19 crisis. Moreover, as the problems of cumbersome bureaucracy and nonjoint decision-making in the EU continue, it will become difficult to implement proposals for the COVID-19 crisis, such as ensuring economic development, economic assistance for businesses, stockpiling vaccines, and distributing vaccines equally to everyone.

\section{REFERENCES}

Adams, D. (2019, July 28). Identity and Democracy Group: United on the Outside, Divided on the Inside, retrieved fromhttps://www.eu-logos.org/2019/06/28/ identity-and-democracy-group-united-on-the-outside-divided-on-theinside/Accessed: 30.12.2020.

Adler, K. (2020, April, 3). Koronavirus outbreak eats into the EU unity, retrieved fromhttps://www.bbc.com/news/world-europe-52135816. Accessed 18 February 2021.

ALDE. (2018, November 8). Freedom, opportunity, prosperity: the Liberal vision for the future of Europe. ALDE Manifesto. Madrid, pp. 1-12. 
Archick, K. and Mix, D. E. (2011). The European Parliament. CRS Report,(21998), pp. 1-16.

Bressanelli, E. (2012). National Parties and Group Membership in the European Parliament: Ideology or Pragmatism. Journal of European Public Policy,9(5), pp. 737-754.

Brotman, A. (2020, May 26). COVID-19 and Democracy in the European Union, retrieved fromhttps://www.e-ir.info/2020/05/26/covid-19-and-democracy-inthe-european-union/. Accessed 20 February 2021.

David, J. and David E. (2003). European Parliament. New York, Palgrave.

ECR. (2013a, December 17). Prague Declaration, retrieved from https://ecrgroup. eu/article/the_prague_declaration. Accessed 31 December 2020.

ECR. (2020) Our History. http://ecrgroup.eu/about-us/our-history/ (Erişim Tarihi: 31.12.2020)

EPP. (2019a). EPP Manifesto: Let's open the next chapter for Europe together, Brussels.

EPP. (2020a, December 28). Our Histor, retrieved fromhttps://www.epp.eu/whowe-are\#timeline. Accessed28 December 2020.

EPP. (2020b, June 11). EPP proposal on the COVID-19 challenge: Calling for EU Health Sovereignty, retrieved fromhttps://www.epp.eu/papers/epp-proposalon-the-covid-19-challenge-calling-for-eu-health-sovereignty/. Accessed 20 February 2021.

ESR. (2020, January 3). Statement by the ESR regarding the coronavirus and possible travel restrictions, retrieved fromhttps://www.myesr.org/ announcement/2631.Accessed22 February 2021.

Euractiv. (2009, May 28). EPP 2009 Manifesto, retrieved fromhttps://www. euractiv.com/section/eu-priorities-2020/linksdossier/2009-european-partymanifestos-at-a-glance/.Accessed 28 December 2020.

Europan Parliament. (2019a, August 19). Parliament Group Priorities: Renew Europea group, retrieved fromhttps://www.europarl.europa.eu/news/en/ headlines/eu-affairs/20190712STO56959/parliament-group-priorities-reneweurope-group. Accessed 30 December 2020.

European Parliament. (2019b, August 18). Parliament group priorities: European conservatives and reformists, retrieved from https://www.europarl.europa. eu/news/en/headlines/eu-affairs/20190712ST056964/parliament-grouppriorities-european-conservatives-and-reformists.Accessed 31 December 2020. 
European Parliament. (2020, May 9). Europe Day - Schuman Declaration Anniversary - 70 Years of Solidarity: statement by Martin SCHIRDEWAN (GUE/NGL, DE), GUE/NGL Group Leader, retrieved from https://multimedia. europarl.europa.eu/en/common-future-post-covid-19-statement-schirdewan _I190767-V_v.Accessed 25 February 2021.

European Parliament. (2021a, February 19). The state of play of the EU's COVID19 Vaccination Strategy, retrieved from https://www.europarl.europa.eu/ doceo/document/CRE-9-2021-02-10-INT-3-018-0000_ES.html.Accessed 22 February 2021.

European Parliament. (2021b, February 18). Preparation of an EU Strategy on COVID-19 vaccination, including its external dimension, retrieved from https://www.europarl.europa.eu/doceo/document/CRE-9-2020-12-16-INT3-123-0000_DE.html.Accessed 22 February 2021..

GUE/NGL. (1994, July 14). Constituent Declaration, retrieved from https://www.gu engl.eu/content/uploads/2019/01/040701-Constituent_declarationAccessed 1 January 2021.

GUE/NGL. (2020a, December 31). History, retrieved from https://www.guengl.eu/ history/Accessed 31 December 2020.

GUE/NGL. (2020b, December 30). About the group, retrieved from https://www.guengl.eu/about-the-group/.Accessed 31 December 2020.

GUE/NGL. (2020c, April 22). COVID-19 exposes the destructive legacy of the Neoliberalism, retrieved fromhttps://www.guengl.eu/covid-19-exposes-thedestructive-legacy-of-neoliberalism/.Accessed 22 February 2021.

Hix, S. Urs, L. (2002). Shaping A Vision A History of the Party of European Socialists 1957-2002, Brussels.

Huet, N. (2019, June 13). Nationalism in the EU has a new name: Identitiy and Democracy, retrieved fromhttps://www.euronews.com/2019/06/13/ nationalism-in-the-eu-has-a-new-name-identity-and-democracy.Accessed 31 December 2020.

Identitiy and Democracy Group. (2019, April 13). Platform, retrieved fromhttps://www.id-party.eu/platform. Accessed 31 December 2020.

Identity and Democracy Group. (2021, January 12). Identity and Democracy party launches massive campaign to expose lies of the European Union and Government during the COVID-19 Crisis, retrieved fromhttps://www.idparty.eu/campaign_covid_19.Accessed 21 February 2021.

Kaczorowska, A. (2009). European Union Law. New York, Routledge. 
Kiriş, H. M. (2013). Avrupa Parlamentosunda Siyasi Gruplar ve Parlamento Seçimleri. [Political Groups in European Parliament and Parliament Elections]. Selçuk Üniversitesi Sosyal Bilimler Enstitüsü Dergisi,(29), pp. 123-135.

Marguand, D. (1979). Parliament for Europe. London, J. Cape.

Nas, Ç. (2020). Koronavirüs Salgınının Yeni Merkez Üssü Avrupa: AB’nin Kriz Yönetimi Sınavı, [New Epicenter of the Coronavirus Outbreak Europe: The EU's Crisis Management Exam], retrieved from https://www.uikpanorama.com/ blog/2020/03/27/koronavirus-salgininin-yeni-merkez-ussu-avrupa-abnin-krizyonetimi-sinavi/. Accessed 5 August 2021.

Official Journal of the European Union. (2012, October 26). Consolidated Version of the Treaty on European Union, retrieved from https://eur-lex.europa.eu/ resource.html? uri=cellar:2bf140bf-a3f8-4ab2-b506-fd71826e6da6.0023. 02/DOC_1\&format=PDF. Accessed 5 August 2021.

Official Journal of the European Union. (2016, June 7). Consolidated Versions of the Treaty on European Union and the Treatyon the Functioning of the European Union 2016/C/202/01, retrieved from https://eur-lex.europa.eu/ legal-content/EN/TXT/HTML/?uri=OJ:C:2016:202:FULL\&from=FR.Accessed 5 August 2021.

Renew Europe. (2019, February 3). Manifesto: For the Renewal of European Democracy, retrieved from https://reneweuropegroup.eu/uploaded/mani festo_for_the_renewal_of_european_democracy.pdf. Accessed 31 December 2020.

Renew Europe. (2020a, December 31). Let's Renew Europe Together, retrieved from https://reneweuropegroup.eu/en/about-us/.Accessed 30 December 2020.

Renew Europe. (2020b, December 30). Our Initiatives, retrieved from https://reneweurope-cor.eu/our-initiatives/. Accessed 30 December 2020.

Renew Europe. (2021, February 2). COVID-19 Updates from Renew Europe Members, retrieved fromhttps://reneweurope-cor.eu/covid-19/. Accessed 22 February 2021.

S\&D. (2020, March 26). Fighting the pandemic together: S\&D COVID-19 Action Plan, retrieved from https://www.socialistsanddemocrats.eu/covid-19-actionplan-europe.Accessed 21 February 2021.

SDRC. (2020, October 21). How COVID has Impacted Early Career Researchers: July 2020 Survey Findings, retrieved from https://www.sdrc.scot/ecr-covidimpact-survey-results-oct20. Accessed 20 February 2021. 
The Greens/EFA. (2020a, December 30) Our Sphere of Actions, retrieved from https://www.greens-efa.eu/en/our-priorities/. Accessed 31 December 2020.

The Green/EFA. (2020b, December 31). About the Group, retrieved from https://www.greens-efa.eu/en/our-group/about-greens-efa/.Accessed 31 December 2020.

The Green/EFA. (2021a, January 19). Corona Crisis, retrieved from https://www. greens-efa.eu/en/priority/group/coronacrisis/. Accessed 23 February 2021.

The Green/EFA. (2021b, February 8). European response to COVID-19 crisis, retrieved fromhttps://www.greens-efa.eu/dossier/european-response-tocovid-19-crisis/ (Erişim Tarihi: 23 February 2021.).

Yatağan, A., Akman, E. ve Kiriş, H. M. (2017). Karşılaştırmalı Çerçevede Avrupa Parlamentosunda Siyasi Gruplar. [Political Groups in European Parliament Within the Comparative Perspective]. KMU Sosyal ve Ekonomik Araştırmalar Dergisi, 19(33), pp. 12-23. 